\title{
A Quantitative Management of Potassium Supply for Hydroponic Production of Low-Potassium Cherry-Type Tomato Fruit for Chronic Kidney Disease Patients
}

\author{
Satoru Tsukagoshi ${ }^{1, *}$, Miho Aoki $^{2}$, Masahumi Johkan ${ }^{3}$, Masaaki Hohjo ${ }^{1}$ and Toru Maruo ${ }^{3}$ \\ 1 Center for Environment, Health and Field Sciences, Chiba University, Kashiwa 277-0882, Japan; \\ hohjo@faculty.chiba-u.jp \\ 2 Faculty of Horticulture, Chiba University, Matsudo 271-8510, Japan; m.aoki29@gmail.com \\ 3 Graduate School of Horticulture, Chiba University, Matsudo 271-8510, Japan; johkan@faculty.chiba-u.jp (M.J.); \\ maruo@faculty.chiba-u.jp (T.M.) \\ * Correspondence: tsukag@faculty.chiba-u.jp
}

check for updates

Citation: Tsukagoshi, S.; Aoki, M.; Johkan, M.; Hohjo, M.; Maruo, T. A Quantitative Management of Potassium Supply for Hydroponic Production of Low-Potassium Cherry-Type Tomato Fruit for Chronic Kidney Disease Patients. Horticulturae 2021, 7, 87. https: / / doi.org/10.3390/horticulturae7040087

Academic Editor: Anastasios Siomos

Received: 15 March 2021

Accepted: 16 April 2021

Published: 19 April 2021

Publisher's Note: MDPI stays neutral with regard to jurisdictional claims in published maps and institutional affiliations.

Copyright: (c) 2021 by the authors. Licensee MDPI, Basel, Switzerland. This article is an open access article distributed under the terms and conditions of the Creative Commons Attribution (CC BY) license (https:// creativecommons.org/licenses/by/ $4.0 /)$.

\begin{abstract}
Chronic kidney disease (CKD) has been a global health problem in recent years. CKD patients often restrict their potassium $(\mathrm{K})$ intake to avoid the high risk of hyperkalemia. In this study, quantitative $\mathrm{K}$ management in hydroponics was adopted to produce low $\mathrm{K}$ cherry-type tomato (Solanum lycopersicom L.) fruit. The total quantity of $\mathrm{K}$ supply per plant during the cultivation was $7.2 \mathrm{~g}(1 \mathrm{~K}), 3.6 \mathrm{~g}(1 / 2 \mathrm{~K}), 1.8 \mathrm{~g}(1 / 4 \mathrm{~K}), 0.9 \mathrm{~g}(1 / 8 \mathrm{~K})$ and $0.6 \mathrm{~g}(1 / 12 \mathrm{~K})$, respectively. The total fruit yield decreased to about $75 \%$ at $1 / 2 \mathrm{~K}$ and $58 \%$ at $1 / 12 \mathrm{~K}$ compared to $1 \mathrm{~K}$. The fruit $\mathrm{K}$ content was lower in $1 / 4 \mathrm{~K}, 1 / 8 \mathrm{~K}$ and $1 / 12 \mathrm{~K}$ than in $1 \mathrm{~K}$ and $1 / 2 \mathrm{~K}$, and the fruit from $1 / 8 \mathrm{~K}$ and $1 / 12 \mathrm{~K}$

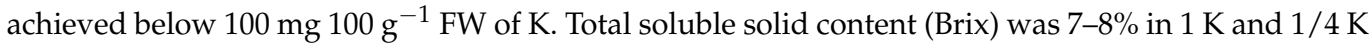
but was lower in $1 / 8 \mathrm{~K}$ and $1 / 12 \mathrm{~K}$. Fruit acid content decreased to $87 \%$ in $1 / 2 \mathrm{~K}$ to $70 \%$ in $1 / 4 \mathrm{~K}$ and $1 / 8 \mathrm{~K}$, and to $57 \%$ in $1 / 12 \mathrm{~K}$ of $1 \mathrm{~K}$. In conclusion, quantitative $\mathrm{K}$ management in hydroponics is expected to produce low $\mathrm{K}$ tomato fruit. Fruit $\mathrm{K}$ content of approximately $100 \mathrm{mg} .100 \mathrm{~g}^{-1} \mathrm{FW}$ was achieved when the quantity of $\mathrm{K}$ supply was $1 / 4 \mathrm{~K}$ and $1 / 8 \mathrm{~K}$, with a relatively smaller effect on fruit yield, Brix and acid content.
\end{abstract}

Keywords: fruit quality; hydroponics; NFT; quantitative fertilizer management; restriction of potassium supply

\section{Introduction}

In recent years, unhealthy choices such as ingestion of excessive fat and salt but fewer vegetables, less exercise, and having inordinate-hours lifestyles, are likely causal factors of diseases, such as hyperlipidemia, hypertension, chronic kidney disease (CKD), and diabetes [1]. We have focused on CKD among these diseases. CKD has been a global health problem, and Global Burden of Disease (GBD) chronic kidney disease collaboration reported that the global all-age mortality rate from CKD increased by 41.5\% between 1990 and 2017, and 1.2 million people died from CKD in 2017 [2]. In addition, GBD 2017 disease and injury incidence and prevalence collaborators reported that the number of individuals with all-stage CKD reached almost 700 million in 2017 [3].

Under normal conditions, the average daily K intake is estimated to be $2000-3900 \mathrm{mg} \cdot$ day $^{-1}$, and approximately $90 \%$ of $\mathrm{K}$ intake is excreted by the kidney to maintain the serum $\mathrm{K}$ concentration within the normal range [4-7]. However, it is difficult for CKD patients to excrete excess $\mathrm{K}$, and their intake of $\mathrm{K}$ is often restricted to $1500 \mathrm{mg} \cdot \mathrm{day}^{-1}$ to avoid the high risk of developing hyperkalemia [8].

The meals for patients on a low-K diet should be prepared not to contain high $\mathrm{K}$, and vegetables are usually soaked in water and boiled to decrease the $\mathrm{K}$ content. However, few recipes involve soaking or boiling lettuce (Lactuca sativa L.) and tomato 
(Solanum lycopersicum L.) before cooking or boiling, making it difficult to use lettuce and tomato as ingredients for patients' meals. If lettuce and/or tomato can be used as raw in the patients' meals, it would lead to patient satisfaction and an improvement in quality of life.

In hydroponic vegetable production, the nutrient solution is usually managed by electrical conductivity (EC) management, that is, the concentration of nutrient ions is maintained at a certain concentration. In EC management, a relatively larger quantity of $\mathrm{K}$ than a necessary and sufficient quantity is absorbed (luxury absorption) because the fertilizers are continuously supplied to the cultivation system to maintain the solution $\mathrm{EC}$, and the plants tend to rapidly absorb $\mathrm{K}$ from the nutrient solution [9]. In addition, $\mathrm{K}$ exists in an ion form in the plant tissue and is not consumed by the synthetic reaction of the plant [10]. Therefore, it is difficult to achieve a stable low K level because the luxury absorbed $\mathrm{K}$ easily moves within the plant parts, and a large quantity of $\mathrm{K}$ usually moves to the fruit when tomato fruit is developing even if $\mathrm{K}$ is withdrawn from the nutrient solution after the beginning of fruit set.

In recent years, a new concept of nutrient management in hydroponics has been proposed. In this concept, the specific weight of the fertilizer is supplied to the cultivation system at regular intervals (quantitative management) regardless of the solution EC [9,11]. For example, if one plant absorbs $1 \mathrm{mg} \mathrm{K}$ a day, the $\mathrm{K}$ fertilizer containing $7 \mathrm{mg} \mathrm{K}$ is added to the cultivation system once a week. Even when the content of nutrients in water fluctuates with this management, absorption of ions from the solution can be performed vigorously under a wide range of solution concentrations with no suppression of plant growth [12]. In fact, Terabayashi et al. showed that tomato was successfully cultivated in hydroponics by supplying nitrate and phosphate once every two weeks [11]. Some approaches to quantitative management have also been reported [13,14].

In this study, we adopted quantitative management to precisely control the K supply in hydroponic tomato production and studied the applicability of the management to produce low $\mathrm{K}$ tomato fruit.

\section{Materials and Methods}

\subsection{Plant Materials and Culture}

The experiment was conducted at Chiba University, located in Matsudo City, Japan (latitude $35^{\circ} 78^{\prime} \mathrm{N}$, longitude $139^{\circ} 90^{\prime}$ E) from 10 September 2014 to 6 February 2015. Seeds of the cherry-type tomato (Solanum lycopersicom L.) 'Carol 10' (Takii Seed Co., Ltd., Kyoto, Japan) were sown on September 10th in 128-cell tray filled with commercial substrate (Tane-Baido, Sumitomo Forestry Landscaping Co., Ltd., Tokyo, Japan, $\mathrm{N}_{2} \mathrm{P}_{2} \mathrm{O}_{5}: \mathrm{K}_{2} \mathrm{O}=$ 150:1600:100 $\mathrm{mg} \cdot \mathrm{L}^{-1}$ ) and placed at $27^{\circ} \mathrm{C}$ in the dark for 3 days. The germinated seeds were then moved into a growth chamber equipped with cool-white fluorescent lamps (Nae Terrace, Mitsubishi Chemical Agri Dream Co., Ltd., Tokyo, Japan). The seedlings were raised under a light/dark period of $14 / 10 \mathrm{~h}$, light/dark temperature of $22 / 18{ }^{\circ} \mathrm{C}_{\text {, a }} \mathrm{CO}_{2}$ concentration of $1000 \mu \mathrm{mol} \cdot \mathrm{mol}^{-1}$ and light intensity of $300 \mu \mathrm{mol} \cdot \mathrm{m}^{-2} \cdot \mathrm{s}^{-1}$. Seedlings were irrigated once or twice a day using 3/4 strength Enshi formula nutrient solution containing $12.0 \mathrm{mM} \mathrm{NO}_{3}{ }^{-}, 1.3 \mathrm{mM} \mathrm{NH}_{4}{ }^{+}, 8.0 \mathrm{mM} \mathrm{K}^{+}, 4.0 \mathrm{mM} \mathrm{Ca}^{2+}, 2.0 \mathrm{mM} \mathrm{Mg}^{2+}, 1.3 \mathrm{mM} \mathrm{H}_{2} \mathrm{PO}_{4}{ }^{-}$, 3.0 ppm Fe, 0.5 ppm Mn, 0.5 ppm B, 0.05 ppm Zn, 0.02 ppm Cu and 0.01 ppm Mo, adjusted to an EC of $0.18 \mathrm{~S} \mathrm{~m}^{-1}$.

Seedlings with 4.5 fully expanded leaves were transplanted on October 2 nd to a nutrient film technique (NFT; closed type) hydroponic system with a slope of $1 \%$ in the greenhouse and a nutrient solution flow rate of $5 \mathrm{~L} \cdot \mathrm{min}^{-1}$. A low node-order pinching and high-density planting system was adopted in this experiment. The plants were set $20 \mathrm{~cm}$ apart on the NFT bed in a single row, and each bed consisted of 24 plants. The distance between the NFT bed was $110 \mathrm{~cm}$, and the final planting density was 4.6 plants $\mathrm{m}^{-2}$. Plants were supported by a linen thread attached to an overhead wire. All lateral shoots were manually removed when they were visible. The plants were pinched off just below the third 
truss around 19 November. The flowers were sprayed with 5 ppm of 4-chlorophenoxyacetic acid (Tomato Tones; ISK Biosciences, Tokyo, Japan) to ensure fruit setting.

The ventilation windows were opened when the air temperature was higher than $25^{\circ} \mathrm{C}$, and the minimum temperature was maintained above $13^{\circ} \mathrm{C}$.

\subsection{Treatment}

In reference to the previous study [11], the total nutrient requirement by the plant was calculated by considering the difference in the estimated final dry mass. Then, the total requirement was divided by the estimated cultivation time, and the quantity of weekly fertilizer requirement was determined.

Treatments consisted of five levels of K supply (Table 1) and $1 \mathrm{~K}$ (Control) were supplied at the determined quantity. The cultivation period was divided into (1) before the 1st flower anthesis (Period 1), (2) after the 1st flower anthesis (Period 2), and (3) after green maturation of the 1st truss (Period 3). The quantity of fertilizer supply was twice as much in Period 2 than in Periods 1 and 3. Four kinds of fertilizers $\left(\mathrm{KNO}_{3}, \mathrm{Ca}\left(\mathrm{NO}_{3}\right)_{2} \cdot 4 \mathrm{H}_{2} \mathrm{O}\right.$, $\mathrm{NH}_{4} \mathrm{H}_{2} \mathrm{PO}_{4}$ and $\mathrm{MgSO}_{4} \cdot 7 \mathrm{H}_{2} \mathrm{O}$ ) were used to supply the nutrients quantitatively. The weekly fertilizer supply in $1 \mathrm{~K}$ in Period 1 was $775 \mathrm{mg} \mathrm{KNO}, 443 \mathrm{mg} \mathrm{Ca}\left(\mathrm{NO}_{3}\right)_{2} \cdot 4 \mathrm{H}_{2} \mathrm{O}$, $288 \mathrm{mg} \mathrm{NH} \mathrm{H}_{2} \mathrm{PO}_{4}$ and $185 \mathrm{mg} \mathrm{MgSO}_{4} \cdot 7 \mathrm{H}_{2} \mathrm{O}$, respectively. The quantity of $\mathrm{K}$ supply was regulated by decreasing the quantity of $\mathrm{KNO}_{3}$, and replacement of $\mathrm{KNO}_{3}$ by $\mathrm{NaNO}_{3}$ was not conducted in this experiment. Therefore, quantity of $\mathrm{N}$ supply decreased according to $\mathrm{K}$ restriction.

Table 1. Fertilization design of each treatment.

\begin{tabular}{cccc}
\hline \multirow{2}{*}{ Treatment } & \multicolumn{3}{c}{ Date and Growth Stage } \\
\cline { 2 - 4 } & Period 1: 2 October-30 October & Period 2: 30 October-11 December & Period 3: 11 December-6 February \\
\cline { 2 - 4 } & Before 1st Flower Anthesis & After 1st Flower Anthesis & After Green Mature of 1st Truss \\
\hline & 300 & Quantity of K Supply (mg/Plant/Week) \\
\hline $\mathrm{K}($ Control $)$ & 150 & 600 & 300 \\
$1 / 2 \mathrm{~K}$ & 75 & 300 & 150 \\
$1 / 4 \mathrm{~K}$ & 37.5 & 150 & 35 \\
$1 / 8 \mathrm{~K}$ & 25 & 55 & 25 \\
$1 / 12 \mathrm{~K}$ & & 50 & 25 \\
\hline
\end{tabular}

Treatment was started immediately after transplanting. Each treatment contained $100 \mathrm{~L}$ of nutrient solution. Tap water was used to prepare the nutrient solution. Water was refilled as much as it decreased, and fertilizers were added to the solution tank every week. Micronutrients were added according to the decreased water volume. The solution was not renewed during the experiment.

\subsection{Measurements}

The water decreasing volume (i.e., plant water uptake) was recorded, and the EC and $\mathrm{K}$ concentrations in the nutrient solution were measured using a compact EC meter and a K ion meter, respectively (LAQUA twin, HORIBA Ltd., Kyoto, Japan).

Fruits were harvested when they turned entirely red by the observation of their appearance, and the fresh weight of each fruit was measured. Fruits above $6 \mathrm{~g}$ were assumed to be marketable fruits, and the weight and number were recorded. The 1st to 3 rd fruits and the 7th to 9th fruits from each truss were used for the evaluation of fruit quality. Seven fruits from each group were randomly selected, and the fresh fruit was cut into small pieces, homogenized, and filtered to obtain the juice. The total soluble solid content and acid content of the juice were measured using a pocket Brix-acidity meter (PAL-BX/ACID3; ATAGO Co., Ltd., Tokyo, Japan) and expressed as Brix $\%$ and citric acid equivalents. The K content in the juice was determined by the potassium test (Merck Co., Ltd., Darmstadt, Germany) using RQ Flex Plus (Merck Co., Ltd., Darmstadt, Germany). 
Plant shoots were collected at the end of the experiment and divided into leaves and stems. When the leaf was defoliated during cultivation, it was collected and stored. The samples were dried at $65^{\circ} \mathrm{C}$ for $72 \mathrm{~h}$, and the dry weight was measured.

\subsection{Data Analysis}

Data were subjected to Tukey's multiple range test $(p<0.05)$ using Excel Statistics Ver. 7 (Esumi Co., Ltd., Tokyo, Japan).

\section{Results}

The total quantity of $\mathrm{K}$ supply per plant was $7.2 \mathrm{~g}$ at $1 \mathrm{~K}, 3.6 \mathrm{~g}$ at $1 / 2 \mathrm{~K}, 1.8 \mathrm{~g}$ at $1 / 4 \mathrm{~K}, 0.9 \mathrm{~g}$ at $1 / 8 \mathrm{~K}$ and $0.6 \mathrm{~g}$ at $1 / 12 \mathrm{~K}$. The cumulative quantity of $\mathrm{K}$ uptake showed that the supplied $\mathrm{K}$ was entirely absorbed by the plants and quantitative management of $\mathrm{K}$ precisely regulated plant $\mathrm{K}$ uptake (Figure 1).

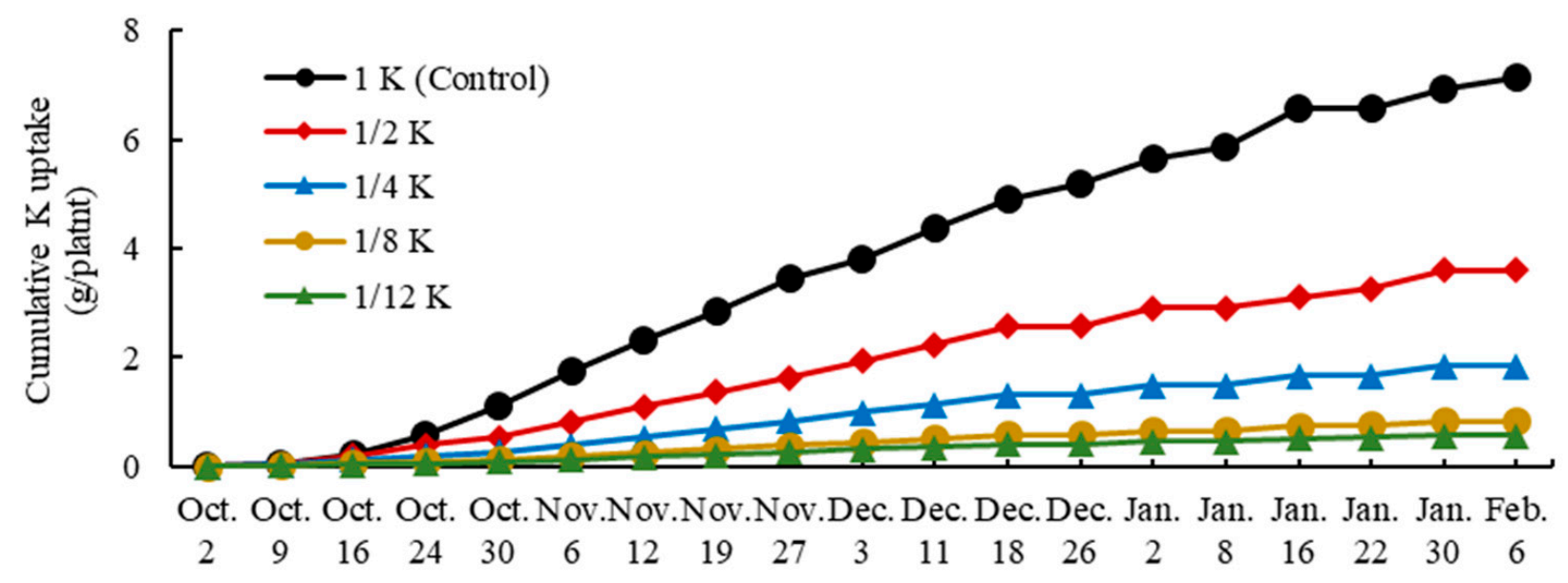

Figure 1. Cumulative quantity of $\mathrm{K}$ uptake per plant in hydroponically grown cherry-type tomato 'Carol 10' under five quantitative K-supply regimes for four months.

The change in solution EC in the $1 \mathrm{~K}$ treatment plot from 24 October to 18 December is shown in Figure 2. The EC increased to approximately $0.13 \mathrm{~S} \cdot \mathrm{m}^{-1}$ when the fertilizers were supplied and gradually decreased to the initial level from 24 October to 24 November, and the minimum and maximum values gradually increased.

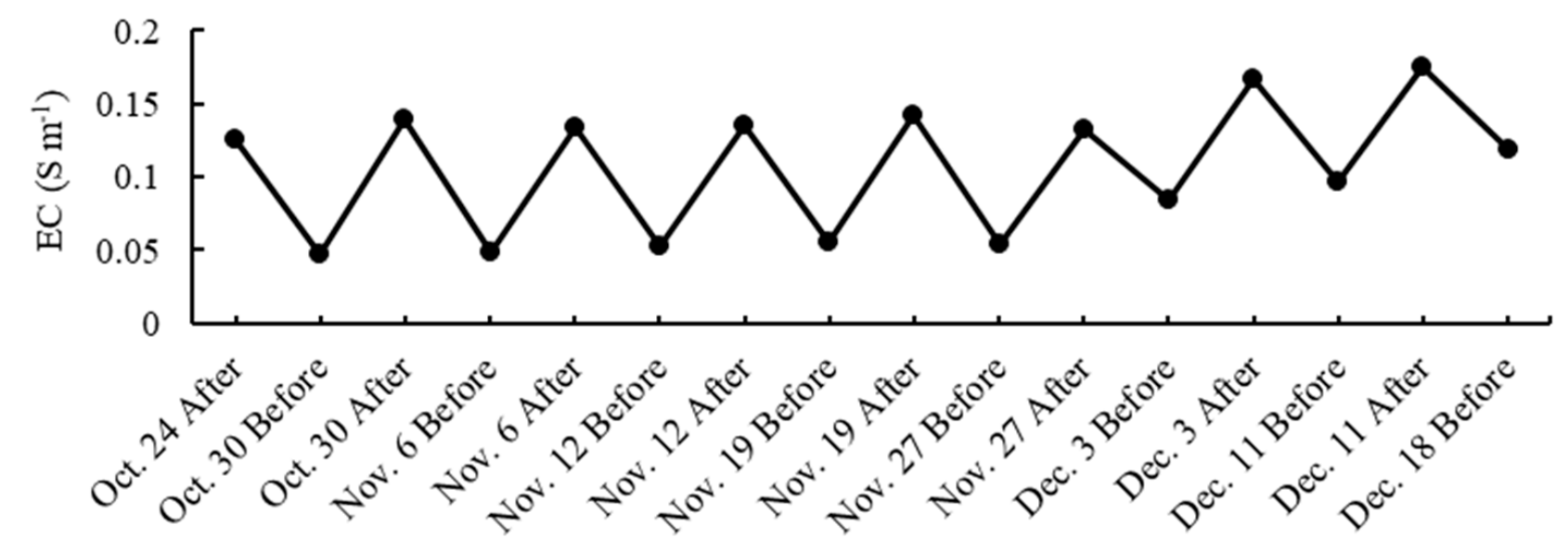

Figure 2. Changes of solution electrical conductivity (EC) before and after quantitative fertilizer application in $1 \mathrm{~K}$ (Control) treatment plot. 
The leaf dry weight at the end of the experiment was lower in all K-restricted treatments than at $1 \mathrm{~K}$, but there was no significant difference between K-restricted treatment (Table 2). The stem dry weight decreased according to the level of $\mathrm{K}$ restriction. In the $1 / 12 \mathrm{~K}$ treatment, the leaf dry weight decreased to $53.3 \%$ and the stem dry weight decreased to $35.5 \%$ compared to those at $1 \mathrm{~K}$.

Table 2. Leaf and stem dry weight of hydroponically grown cherry-type tomato plants at the end of the experiment under five quantitative K-supply regimes.

\begin{tabular}{ccc}
\hline $\begin{array}{c}\text { K } \\
\text { Supply }\end{array}$ & $\begin{array}{c}\text { Leaf } \\
\text { (g/Plant) }\end{array}$ & $\begin{array}{c}\text { Stem } \\
\text { (g/Plant) }\end{array}$ \\
\hline $1 \mathrm{~K}$ & $63.6 \pm 1.6^{1} \mathrm{a}^{2}$ & $41.1 \pm 0.8 \mathrm{a}$ \\
$1 / 2 \mathrm{~K}$ & $45.1 \pm 3.6 \mathrm{~b}$ & $37.1 \pm 0.4 \mathrm{~b}$ \\
$1 / 4 \mathrm{~K}$ & $35.9 \pm 1.5 \mathrm{~b}$ & $28.5 \pm 1.1 \mathrm{c}$ \\
$1 / 8 \mathrm{~K}$ & $33.5 \pm 3.3 \mathrm{~b}$ & $17.4 \pm 0.5 \mathrm{~d}$ \\
$1 / 12 \mathrm{~K}$ & $33.9 \pm 0.9 \mathrm{~b}$ & $14.6 \pm 0.8 \mathrm{~d}$ \\
\hline
\end{tabular}

${ }^{1}$ Mean \pm SE $(n=3) .{ }^{2}$ Means in the same column with different letters are significantly different by Tukey's multiple range test at $p<0.05$.

The outlooks of the plants in each treatment were shown in Figure 3. The plants in $1 \mathrm{~K}$ looked healthy and vigorous, and plant growth gradually became weaker according to the decrease of K supply. The lower leaves showed severe K deficit symptom when K supply was below the level of $1 / 4 \mathrm{~K}$.

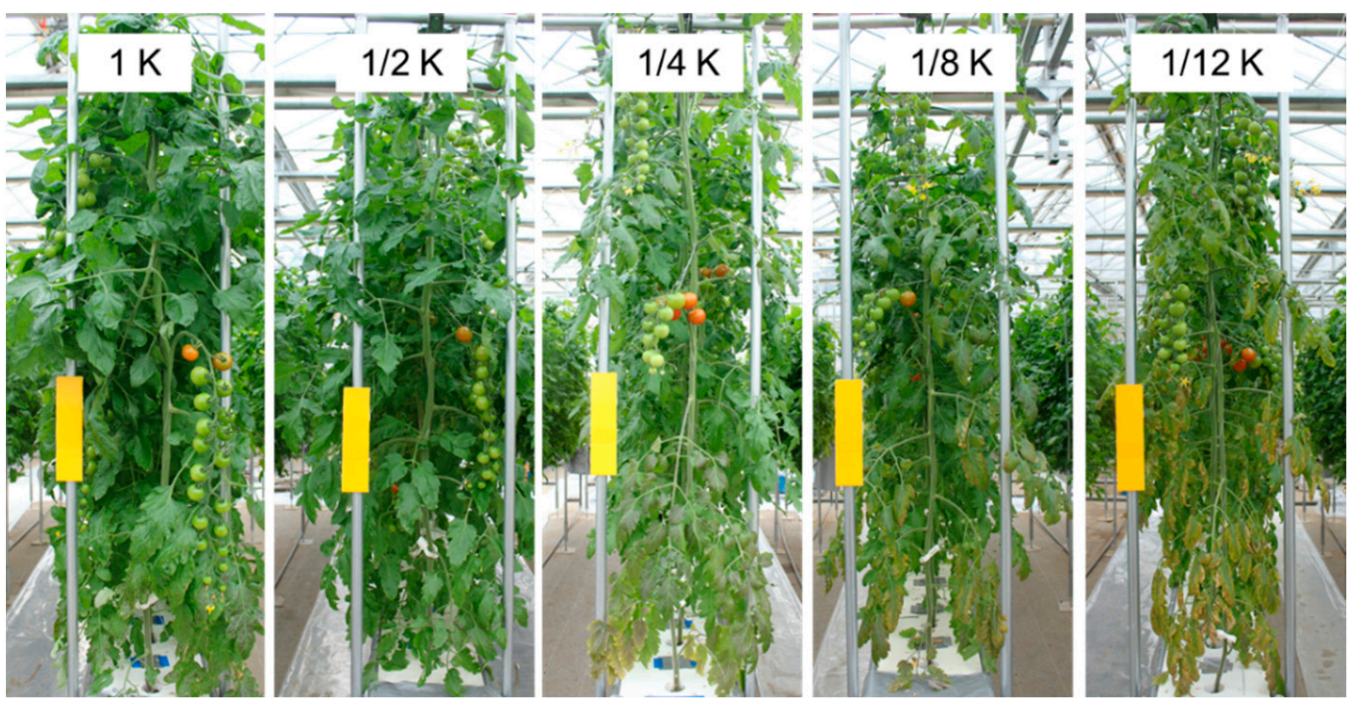

Figure 3. Outlooks of hydroponically grown cherry-type tomato 'Carol 10' under five K-supply regimes just before starting the fruit harvest.

The cumulative water uptake decreased according to the level of K restriction (Figure 4). The decrease might be caused by the lower leaf and stem growth; however, the water uptake at $1 / 12 \mathrm{~K}$ decreased to $73.9 \%$ compared to that in $1 \mathrm{~K}$.

The fruit yield from the 1 st truss was not different between $1 \mathrm{~K}, 1 / 2 \mathrm{~K}$ and $1 / 4 \mathrm{~K}$, and it was lower in the $1 / 8 \mathrm{~K}$ and $1 / 12 \mathrm{~K}$ treatments than at $1 \mathrm{~K}$ (Table 3 ). However, the yield from the second truss decreased in most of the K-restricted treatment compared to $1 \mathrm{~K}$. Consequently, the total yield decreased to about $75 \%$ at $1 / 2 \mathrm{~K}$ and at $1 / 4 \mathrm{~K}, 65 \%$ at $1 / 8 \mathrm{~K}$, and $58 \%$ at $1 / 12 \mathrm{~K}$ compared to $1 \mathrm{~K}$. The total number of fruits harvested showed the same trend as the fruit yield. 


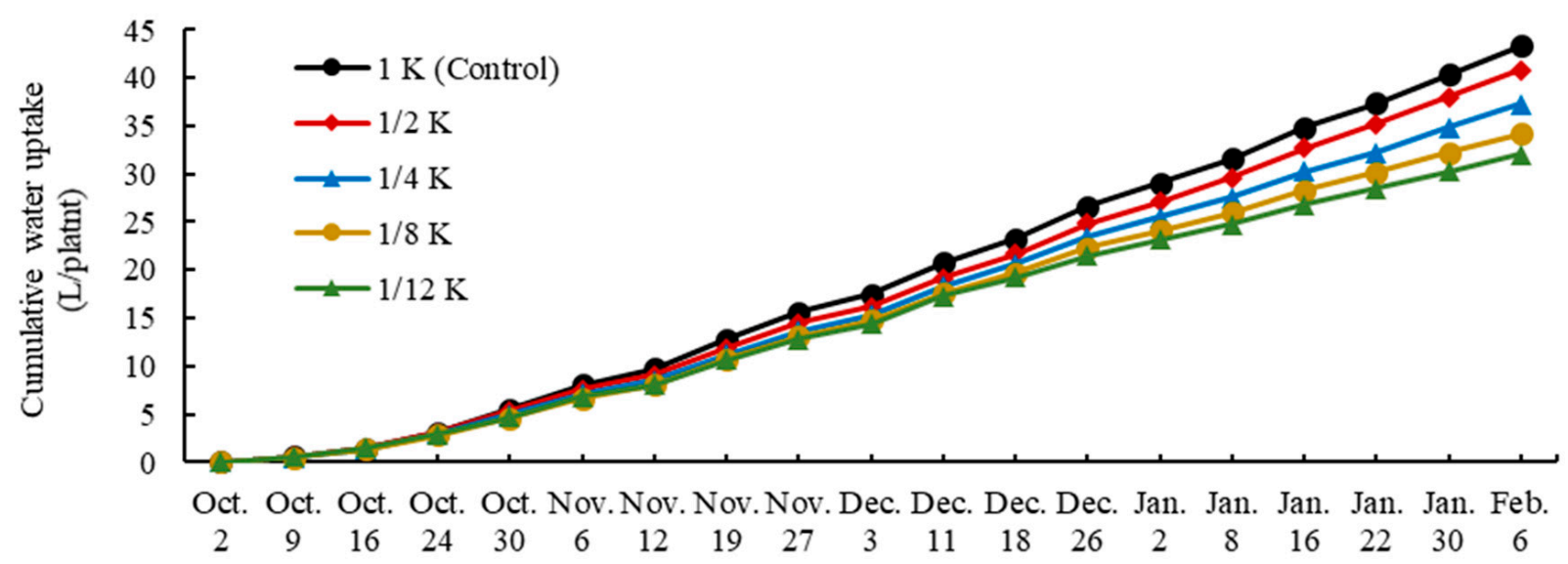

Figure 4. Cumulative water uptake per plant under five quantitative K-supply regimes for four months in hydroponically grown cherry-type tomato 'Carol 10'.

Table 3. Fruit marketable yield ${ }^{1}$ of hydroponically grown cherry-type tomato 'Carol $10^{\prime}$ under five quantitative K-supply regimes.

\begin{tabular}{ccccccc}
\hline \multirow{2}{*}{$\begin{array}{c}\text { K } \\
\text { Supply }\end{array}$} & \multicolumn{3}{c}{ Yield (g/Plant) } & \multicolumn{3}{c}{ No. of Fruits (Fruits/Plant) } \\
\cline { 2 - 7 } & 1st Truss & 2nd Truss & Total & 1st Truss & 2nd Truss & Total \\
\hline $1 \mathrm{~K}$ & $352.6 \pm 22.0^{2} \mathrm{a}^{3}$ & $313.1 \pm 16.9 \mathrm{a}$ & $665.7 \pm 25.9 \mathrm{a}$ & $20.8 \pm 2.0 \mathrm{a}$ & $17.5 \pm 1.2 \mathrm{~ns}$ & $38.3 \pm 1.6 \mathrm{a}$ \\
$1 / 2 \mathrm{~K}$ & $285.4 \pm 28.0 \mathrm{a}$ & $229.5 \pm 14.3 \mathrm{~b}$ & $502.6 \pm 23.4 \mathrm{~b}$ & $16.0 \pm 1.6 \mathrm{a}$ & $12.7 \pm 0.8$ & $28.1 \pm 0.9 \mathrm{~b}$ \\
$1 / 4 \mathrm{~K}$ & $267.8 \pm 15.8 \mathrm{a}$ & $241.6 \pm 10.3 \mathrm{~b}$ & $509.5 \pm 22.5 \mathrm{~b}$ & $16.0 \pm 3.5 \mathrm{a}$ & $15.2 \pm 0.8$ & $31.3 \pm 1.6 \mathrm{~b}$ \\
$1 / 8 \mathrm{~K}$ & $168.0 \pm 20.6 \mathrm{~b}$ & $264.0 \pm 12.3 \mathrm{ab}$ & $432.0 \pm 21.3 \mathrm{bc}$ & $10.9 \pm 1.0 \mathrm{ab}$ & $14.3 \pm 0.8$ & $25.1 \pm 1.2 \mathrm{Bc}$ \\
$1 / 12 \mathrm{~K}$ & $143.1 \pm 19.7 \mathrm{~b}$ & $243.2 \pm 12.1 \mathrm{~b}$ & $386.3 \pm 16.4 \mathrm{c}$ & $10.5 \pm 0.8 \mathrm{~b}$ & $13.6 \pm 0.4$ & $24.1 \pm 0.7 \mathrm{c}$ \\
\hline
\end{tabular}

${ }^{1}$ Fruits measuring more than $6 \mathrm{~g}$ were recorded. ${ }^{2}$ Mean $\pm \mathrm{SE}(n=8) .{ }^{3}$ Means in the same column with different letters are significantly different by Tukey's multiple range test at $p<0.05$.

The fruit $\mathrm{K}$ content showed the same trend both in first and second fruit truss. Average $\mathrm{K}$ content was not affected by $1 / 2 \mathrm{~K}$ treatment but was lower at $1 / 4 \mathrm{~K}, 1 / 8 \mathrm{~K}$ and $1 / 12 \mathrm{~K}$ than at $1 \mathrm{~K}$ (Table 4).

Table 4. Fruit K content of hydroponically grown cherry-type tomato 'Carol 10' under five quantitative K-supply regimes.

\begin{tabular}{|c|c|c|c|c|c|}
\hline \multirow{2}{*}{$\begin{array}{c}\text { K } \\
\text { Supply }\end{array}$} & \multicolumn{2}{|c|}{ 1st Truss } & \multicolumn{2}{|c|}{ 2nd Truss } & \multirow{2}{*}{$\begin{array}{c}\text { Total } \\
\text { Average }\end{array}$} \\
\hline & 1st-3rd Fruit ${ }^{1}$ & 7th-9th Fruit & 1st-3rd Fruit & 7th-9th Fruit & \\
\hline & \multicolumn{5}{|c|}{$\left(\mathrm{mg} 100 \mathrm{~g}^{-1} \mathrm{FW}\right)$} \\
\hline $1 \mathrm{~K}$ & $164.3 \pm 5.7^{2} \mathrm{a}^{3}$ & $168.6 \pm 6.7 \mathrm{a}$ & $127.1 \pm 6.8 \mathrm{a}$ & $147.1 \pm 3.6 \mathrm{a}$ & $151.8 \pm 4.2 \mathrm{a}$ \\
\hline $1 / 2 \mathrm{~K}$ & $167.1 \pm 6.1 \mathrm{a}$ & $140.0 \pm 5.3 b$ & $128.6 \pm 5.1 \mathrm{a}$ & $134.3 \pm 3.7 \mathrm{a}$ & $142.5 \pm 3.7 \mathrm{a}$ \\
\hline $1 / 4 \mathrm{~K}$ & $114.3 \pm 3.7 \mathrm{~b}$ & $105.1 \pm 8.4 c$ & $96.1 \pm 4.4 b$ & $115.0 \pm 5.2 \mathrm{~b}$ & $107.6 \pm 3.1 b$ \\
\hline $1 / 8 \mathrm{~K}$ & $88.9 \pm 4.7 \mathrm{c}$ & $76.0 \pm 3.3 \mathrm{~d}$ & $74.7 \pm 4.2 c$ & $69.9 \pm 2.4 c$ & $76.4 \pm 2.0 c$ \\
\hline $1 / 12 \mathrm{~K}$ & $77.4 \pm 2.2 c$ & $46.6 \pm 3.0 \mathrm{e}$ & $63.4 \pm 3.3 c$ & $54.7 \pm 3.6 c$ & $60.5 \pm 2.6 \mathrm{~d}$ \\
\hline
\end{tabular}

${ }^{1}$ Fruit position counted from the proximal part of each fruit truss. ${ }^{2}$ Mean \pm SE $(n=7$, total average; $n=28)$

${ }^{3}$ Means in the same column with different letters are significantly different by Tukey's multiple range test at $p<0.05$.

The total soluble solid content (Brix) was $7-8 \%$ and was not significantly different by the quantity of $\mathrm{K}$ supply between $1 \mathrm{~K}$ and $1 / 8 \mathrm{~K}$ at any fruit position (Table 5). In average, it was not affected between $1 \mathrm{~K}$ and $1 / 4 \mathrm{~K}$, and is lower at $1 / 8 \mathrm{~K}$ and $1 / 12 \mathrm{~K}$. 
Table 5. Fruit total soluble solid content of hydroponically grown cherry-type tomato 'Carol 10' under five quantitative K-supply regimes.

\begin{tabular}{cccccc}
\hline \multirow{2}{*}{$\begin{array}{c}\text { K } \\
\text { Supply }\end{array}$} & \multicolumn{2}{c}{ 1st Truss } & \multicolumn{2}{c}{ 2nd Truss } & \multirow{2}{*}{$\begin{array}{c}\text { Total } \\
\text { Average }\end{array}$} \\
\cline { 2 - 5 } & 1st-3rd Fruit $^{\text {1 }}$ & 7th-9th Fruit & 1st-3rd Fruit & 7th-9th Fruit & \\
\hline & & & (Brix\%) & \\
$1 \mathrm{~K}$ & $7.6 \pm 0.2^{2} \mathrm{a}^{3}$ & $6.9 \pm 0.1 \mathrm{a}$ & $7.5 \pm 0.1 \mathrm{a}$ & $7.8 \pm 0.2 \mathrm{a}$ & $7.4 \pm 0.1 \mathrm{a}$ \\
$1 / 2 \mathrm{~K}$ & $8.1 \pm 0.2 \mathrm{a}$ & $7.5 \pm 0.4 \mathrm{a}$ & $8.1 \pm 0.3 \mathrm{a}$ & $7.8 \pm 0.4 \mathrm{a}$ & $7.8 \pm 0.2 \mathrm{a}$ \\
$1 / 4 \mathrm{~K}$ & $7.7 \pm 0.3 \mathrm{a}$ & $7.9 \pm 0.4 \mathrm{a}$ & $7.4 \pm 0.4 \mathrm{ab}$ & $8.5 \pm 0.6 \mathrm{a}$ & $7.8 \pm 0.2 \mathrm{a}$ \\
$1 / 8 \mathrm{~K}$ & $6.9 \pm 0.4 \mathrm{ab}$ & $6.6 \pm 0.3 \mathrm{ab}$ & $6.8 \pm 0.2 \mathrm{ab}$ & $6.6 \pm 0.4 \mathrm{ab}$ & $6.7 \pm 0.2 \mathrm{~b}$ \\
$1 / 12 \mathrm{~K}$ & $5.8 \pm 0.4 \mathrm{~b}$ & $5.5 \pm 0.3 \mathrm{~b}$ & $6.4 \pm 0.3 \mathrm{~b}$ & $6.0 \pm 0.3 \mathrm{~b}$ & $6.0 \pm 0.2 \mathrm{c}$ \\
\hline
\end{tabular}

${ }^{1}$ Fruit position counted from the proximal part of each fruit truss. ${ }^{2}$ Mean \pm SE $(n=10$, total average; $n=40)$

${ }^{3}$ Means in the same column with different letters are significantly different by Tukey's multiple range test at $p<0.05$.

The fruit acid content strongly affected by the restriction of $\mathrm{K}$ supply, and decreased to $87 \%$ at $1 / 2 \mathrm{~K}$, to $70 \%$ at $1 / 4 \mathrm{~K}$ and $1 / 8 \mathrm{~K}$ and to $57 \% 1 / 12$ at $1 \mathrm{~K}$ (Table 6 ).

Table 6. Fruit acid content of hydroponically grown cherry-type tomato 'Carol 10' under five quantitative K-supply regimes.

\begin{tabular}{cccccc}
\hline \multirow{2}{*}{$\begin{array}{c}\text { K } \\
\text { Supply }\end{array}$} & \multicolumn{2}{c}{ 1st Truss } & \multicolumn{2}{c}{ 2nd Truss } & \multirow{2}{*}{ Total Average } \\
\cline { 2 - 5 } & 1st-3rd Fruit $^{\mathbf{1}}$ & 7th-9th Fruit & 1st-3rd Fruit & 7th-9th Fruit & \\
\hline & & & $\left(\%{ }^{2}\right)$ & & \\
$1 \mathrm{~K}$ & $0.47 \pm 0.01^{3} \mathrm{a}$ & $0.49 \pm 0.01 \mathrm{a}$ & $0.47 \pm 0.03 \mathrm{a}$ & $0.45 \pm 0.03 \mathrm{a}$ & $0.47 \pm 0.01 \mathrm{a}$ \\
$1 / 2 \mathrm{~K}$ & $0.44 \pm 0.01 \mathrm{ab}$ & $0.46 \pm 0.01 \mathrm{ab}$ & $0.43 \pm 0.03 \mathrm{ab}$ & $0.33 \pm 0.04 \mathrm{ab}$ & $0.41 \pm 0.02 \mathrm{ab}$ \\
$1 / 4 \mathrm{~K}$ & $0.35 \pm 0.03 \mathrm{abc}$ & $0.34 \pm 0.04 \mathrm{bc}$ & $0.37 \pm 0.04 \mathrm{ab}$ & $0.30 \pm 0.02 \mathrm{ab}$ & $0.34 \pm 0.02 \mathrm{bc}$ \\
$1 / 8 \mathrm{~K}$ & $0.36 \pm 0.02 \mathrm{bc}$ & $0.37 \pm 0.02 \mathrm{bc}$ & $0.34 \pm 0.02 \mathrm{ab}$ & $0.26 \pm 0.03 \mathrm{~b}$ & $0.33 \pm 0.01 \mathrm{bc}$ \\
$1 / 12 \mathrm{~K}$ & $0.27 \pm 0.02 \mathrm{c}$ & $0.28 \pm 0.03 \mathrm{c}$ & $0.29 \pm 0.02 \mathrm{~b}$ & $0.22 \pm 0.02 \mathrm{~b}$ & $0.27 \pm 0.01 \mathrm{c}$ \\
\hline
\end{tabular}

${ }^{1}$ Fruit position counted from the proximal part of each fruit truss. ${ }^{2}$ Acid content expressed as citric acid equivalent. ${ }^{3}$ Mean $\pm \mathrm{SE}(n=5$, total average; $n=20) .{ }^{4}$ Means in the same column with different letters are significantly different by Tukey's multiple range test at $p<0.05$.

\section{Discussion}

The total quantity of $\mathrm{K}$ supply per plant was $7.2 \mathrm{~g}$ at $1 \mathrm{~K}, 3.6 \mathrm{~g}$ at $1 / 2 \mathrm{~K}, 1.8 \mathrm{~g}$ at $1 / 4 \mathrm{~K}$, $0.9 \mathrm{~g}$ at $1 / 8 \mathrm{~K}$ and $0.6 \mathrm{~g}$ at $1 / 12 \mathrm{~K}$. The cumulative quantity of $\mathrm{K}$ uptake was nearly the same as K supply (Figure 1) and this showed that the supplied K was entirely absorbed by the plants and quantitative management of $\mathrm{K}$ precisely regulated plant $\mathrm{K}$ uptake.

Under the quantitative management, solution EC repeats the increase and decrease. When plants totally absorb the nutrients, the minimum and maximum values should be kept at a certain level. However, minimum and maximum values gradually increased (Figure 2). The tap water used in this study contained a slightly high concentrations of $\mathrm{Ca}$, $\mathrm{Mg}$ and $\mathrm{SO}_{4}$, and its EC was $0.043 \mathrm{~S} \mathrm{~m}^{-1}$. These results indicated that the fertilizers were entirely absorbed by the plants every week, but ions such as $\mathrm{Ca}, \mathrm{Mg}$ and $\mathrm{SO}_{4}$ seemed to accumulate in the solution after pinching of the stem.

$\mathrm{K}$ restriction affected leaf and shoot dry weight (Table 2), and the decrease of shoot dry weight was bigger, even though the plants showed $\mathrm{K}$ deficit symptom on the lower leaves (Figure 3). Kanai et al. reported that $\mathrm{K}$ withdrawal from the fruiting stage of tomato plants and $\mathrm{K}$ deficiency led to more suppressed stem growth than leaves and root growth [15]. Gerardeaux et al. also reported that K deficiency strongly decreased dry matter partitioning in the stems of cotton plants [16]. The same trend was observed when $\mathrm{K}$ restriction was more strongly affected by stem dry weight than leaf dry weight in this experiment. In addition, the main role of $\mathrm{K}$ in plant is the regulation of internal $\mathrm{pH}$ and osmotic potential and is relating to various metabolic and synthetic reactions [9] and decrease of osmotic potential in leaves by $\mathrm{K}$ make water movement from root zone to leaves [17]. Cumulative water uptake decreased according to decreasing K supply (Figure 4), and this might affect the nutrient uptake and lead to the decrease of leaf and stem dry weight. In addition, some 
extent of $\mathrm{N}$ supply was also restricted because $\mathrm{KNO}_{3}$ quantity was restricted to regulating $\mathrm{K}$ supply to the plants, and the decrease of $\mathrm{N}$ supply could affect leaf and stem dry weight. Using $\mathrm{NaNO}_{3}$ instead of $\mathrm{KNO}_{3}$ may be available to maintain plant growth.

The total fruit yield and the total number of fruits decreased by K restriction (Table 3). Besford and Maw reported that low $\mathrm{K}$ levels in the nutrient solution retarded the vegetative growth, flowering and fruit set of tomato plants [18]. In this experiment, the average fruit weight was 16-17 g, and there was no significant difference between treatments (data not shown). Therefore, the decrease in fruit yield due to $\mathrm{K}$ restriction in this experiment was supposed to result from the decrease in the fruit set. Besides, K restriction could affect dry matter production and partitioning due to the change of water and nutrient status, then the growth was suppressed, and the fruit yield decreased.

In addition to this, a plant generally has a lower $\mathrm{K}$ content in the leaves when it grows under low K conditions $[19,20]$. For hydroponic lettuce production, a cultivation method to produce low $\mathrm{K}$ lettuce has already been developed [21,22], and its production has been put to practical use. In the case of lettuce production, $\mathrm{KNO}_{3}$ in the nutrient solution was withdrawn from the solution or replaced by $\mathrm{NaNO}_{3}$ from a certain growth stage [23], and the $\mathrm{K}$ content in lettuce leaves decreased. This means that the continuous growth after $\mathrm{K}$ withdrawal dilutes $\mathrm{K}$ content in lettuce leaves. Thus, the mechanism to obtain low-K lettuce is simple. In the case of tomato, sufficient $\mathrm{K}$ must be supplied to permit normal vegetative growth and ensure fruit yield and quality. On the other hand, fruit $\mathrm{K}$ content should be regulated as a certain lower level. Therefore, $\mathrm{K}$ supply regime is more important strategy to produce low-K tomato fruit compared to produce low-K lettuce. In our previous study using single truss tomato production system, $\mathrm{K}$ uptake by tomato plant decreased to $10 \%$ by $\mathrm{K}$ restriction, but fruit K content only decreased to $75 \%$ compared to control [24]. This suggested that low-K tomato fruit can be obtained when the condition of $\mathrm{K}$ supply is severe to suppress vegetative growth of the plant.

According to the fruit yield, we did not set EC control plot and we could not compare between $1 \mathrm{~K}$ treatment and EC control. However, the yield of cherry-type tomato in Japan is usually 120-150 ton/ha/year [25]. The system we adopted can repeat the cultivation $3.5-4$ times a year, and planting density was 4.6 plants $\mathrm{m}^{-2}$. Therefore, the yearly yield of $1 \mathrm{~K}$ will be 108-123 ton/ha/year. This suggests that $\mathrm{K}$ supply can be reduced to $1 \mathrm{~K}$ level without any adverse effect on tomato growth and yield.

The fruit $\mathrm{K}$ was lower at $1 / 4 \mathrm{~K}, 1 / 8 \mathrm{~K}$ and $1 / 12 \mathrm{~K}$ than at $1 \mathrm{~K}$ (Table 4 ). A leaf lettuce (Lactuca sativa L.) called 'low-K lettuce' has been commercially produced in Japan and claims to contain below $100 \mathrm{mg} 100 \mathrm{~g}^{-1} \mathrm{FW}$ of $\mathrm{K}$. Although, there is currently no scientific $\mathrm{K}$ value defining a low-K vegetable, only fruit from $1 / 8 \mathrm{~K}$ and $1 / 12 \mathrm{~K}$ achieved below $100 \mathrm{mg} 100 \mathrm{~g} \mathrm{~g}^{-1} \mathrm{FW}$ of $\mathrm{K}$ when the criterion was this value. In addition, the standard value of fruit $\mathrm{K}$ content of cherry-type tomato in the standard tables of food composition in Japan is $290 \mathrm{mg} 100 \mathrm{~g} \mathrm{~g}^{-1} \mathrm{FW}$ [26], and fruit $\mathrm{K}$ content at $1 \mathrm{~K}$ was markedly lower than this value. This suggested that the tomato plants often absorb K more than necessary (luxury absorption) under general cultivation systems, and quantitative management adopted in this experiment avoided the luxury absorption and reduced the fruit $\mathrm{K}$ content even at $1 \mathrm{~K}$.

Although the standard Brix value of cherry-type tomato fruit has been unidentified because it depends on the cultivar, production season, cultivation method, etc., $7-8 \%$ seemed to be a regular value of this cultivar from some results of another examination that we performed (unpublished). The standard value of fruit acid content of cherry-type tomato in the standard tables of food composition in Japan [26] is $0.6 \%$, and the acid content at $1 \mathrm{~K}$ was lower than the standard value. Bradley reported that the acid content of tomato fruit increased with increased exchangeable K in soil [27], and Sakiyama reported that the acid and $\mathrm{K}$ content in tomato fruit exhibited a positive correlation [28]. As a result of having avoided the luxury absorption of $\mathrm{K}$ by quantitative management, the acid content decreased even at $1 \mathrm{~K}$, and strongly affected the fruit acid content when $\mathrm{K}$ supply was restricted. In addition, the decreasing ratio of acid content was greater than that of Brix (Tables 5 and 6), suggesting that further experiments on fruit taste are necessary. 


\section{Conclusions}

1. Quantitative management can avoid the luxury absorption of K in hydroponic tomato production and precisely regulate the $\mathrm{K}$ supply to the plant.

2. Fruit $\mathrm{K}$ content of approximately $100 \mathrm{mg} 100 \mathrm{~g}^{-1} \mathrm{FW}$ was achieved when the quantity of $\mathrm{K}$ supply was $1 / 4 \mathrm{~K}$ and $1 / 8 \mathrm{~K}$.

3. Total soluble solid content of fruit was not affected in $1 / 4 \mathrm{~K}$, and decreased to $90 \%$ in $1 / 8 \mathrm{~K}$, and acid content of fruit decreased to $70 \%$ in $1 / 4 \mathrm{~K}$ and $1 / 8 \mathrm{~K}$.

4. We could assume that the critical quantity of $\mathrm{K}$ supply was around $1 / 4 \mathrm{~K}(1.8 \mathrm{~g} \mathrm{~K} /$ plant with 2 truss) to achieve low-K tomato fruit production with normal quality.

5. A combination of low node-order pinching and high-density planting system with quantitative $\mathrm{K}$ management is promising for the stable production of low $\mathrm{K}$ tomato.

6. Further study to achieve all-year-round production of low-K tomato fruits should be necessary.

7. This management method could apply to the other fruit vegetable production, such as low-K cucumber and low-K strawberry.

Author Contributions: Conceptualization, S.T. and T.M.; Investigation, S.T. and M.A.; Methodology, S.T. and T.M.; Writing—original draft, S.T. and M.J.; Writing—review \& editing, M.H. and T.M. All authors have read and agreed to the published version of the manuscript.

Funding: This research received no external funding.

Institutional Review Board Statement: Not applicable.

Informed Consent Statement: Not applicable.

Data Availability Statement: Data is contained within the article.

Conflicts of Interest: The authors declare no conflict of interest.

\section{References}

1. Ikegami, F.; Wang, Y.; Kaneko, M.; Sumino, M.; Tsukagoshi, S. Human health sciences -from cultivation to utilization of medicinal plants. OJPM 2012, 2, 214-224. [CrossRef]

2. GBD Chronic Kidney Disease Collaboration. Global, regional, and national burden of chronic kidney disease, 1990-2017: A systematic analysis for the global burden of disease study 2017. Lancet 2020, 395, 709-733. [CrossRef]

3. GBD 2017 Disease and Injury Incidence and Prevalence Collaborators. Global, regional, and national incidence, prevalence, and years lived with disability for 354 diseases and injuries for 195 countries and territories, 1990-2017: A systematic analysis for the Global Burden of Disease Study 2017. Lancet 2018, 392, 1789-1858. [CrossRef]

4. Choi, H.Y.; Ha, S.K. Potassium balances in maintenance hemodialysis. Electro. Blood Press. 2013, 11, 9-16. [CrossRef] [PubMed]

5. Kes, P. Hyperkalemia: A potentially lethal clinical condition. Acta Clin. Croat. 2001, 40, 215-225.

6. Putcha, N.; Allon, M. Management of hyperkalemia in dialysis patients. Semin. Dial. 2007, 20, 431-439. [CrossRef] [PubMed]

7. Weiner, I.D.; Wingo, C.S. Hyperkalemia: A potential silent killer. J. Am. Soc. Nephrol. 1998, 9, 1535-1543.

8. Committee for Revision of Diet Therapy Guideline. Dietary recommendations for chronic kidney disease 2007. Jpn. J. Nephro. 2007, 49, 871-878. (In Japanese)

9. Tsukagoshi, S.; Shinohara, Y. Nutrition and Nutrient Uptake in Hydroponic System. In Plant Factory; An Indoor Vertical Farming System for Efficient Quality Food Production, 1st ed.; Kozai, T., Niu, G., Takagaki, M., Eds.; Academic Press: Cambridge, MA, USA, 2015; pp. 165-172.

10. Tsukagoshi, S.; Yamori, W. Beneficial effects of various environmental stresses on vegetables and medicinal plants for the production of high value-added plants. In Handbook of Plant and Crop Stress, 4th ed.; Passarakli, M., Ed.; CRC Press: Boca Raton, FL, USA, 2019; pp. 909-917.

11. Terabayashi, S.; Asaka, T.; Tomatsuri, A.; Date, S.; Fujime, Y. Effect of the limited supply of nitrate and phosphate on nutrient uptake and fruit production of tomato (Lycopersicon esculentum Mill.) in hydroponic culture. Hortic. Res. 2004, 3, 195-200, (In Japanese with English abstract). [CrossRef]

12. Maruo, T.; Takagaki, M.; Shinohara, Y. Critical Nutrient Concentrations for Absorption of Some Vegetables. Acta Hortic. 2004, 44, 493-499. [CrossRef]

13. Li, H.; Inokuchi, T.; Nagaoka, T.; Tamura, M.; Hamada, S.; Suzuki, S. $\mathrm{NO}_{3}{ }^{-}$requirement and the quantitative management method of nutrient solution based on $\mathrm{NO}_{3}{ }^{-}$supply in hydroponic culture of radish plants. J. Jpn. Soc. Hortic. Sci. 2014, 83, 44-51. [CrossRef] 
14. Nakano, Y.; Sasaki, H.; Nakano, A.; Suzuki, K.; Takaichi, M. Growth and yield of tomato plants as influenced by nutrient application rates with quantitative control in closed rockwool cultivation. J. Jpn. Soc. Hortic. Sci. 2010, 79, 47-55. [CrossRef]

15. Kanai, S.; Ohkura, K.; Adu-Gyamfi, J.J.; Mohapatra, P.K.; Nguyen, N.T.; Saneoka, H.; Fujita, K. Depression of sink activity precedes the inhibition of biomass production in tomato plants subjected to potassium deficiency stress. J. Exp. Bot. 2007, 58, 2917-2928. [CrossRef]

16. Gerardeaux, E.; Jordan-Meille, L.; Constantin, J.; Pllerin, S.; Dingkuhn, M. Changes in plant morphology and dry matter partitioning caused by potassium deficiency in Gossypium hirsutum (L.). Environ. Exp. Bot. 2010, 67, 451-459. [CrossRef]

17. Matou, T. Physiological activity of potassium. In Textbook of Plant Nutrition and Fertilizer; Asakura Publishing Co., Ltd.: Tokyo, Japan, 2010; pp. 101-105. (In Japanese)

18. Besford, R.T.; Maw, G.A. Effect of potassium nutrition on tomato plant growth and fruit development. Plant Soil 1975, 42, 395-412. [CrossRef]

19. Asao, T.; Asaduzzaman, M.D.; Mondal, M.D.; Tokura, M.; Adachi, F.; Ueno, M.; Kawaguchi, M.; Yano, S.; Ban, T. Impact of reduced potassium nitrate concentrations in nutrient solution on the growth, yield and fruit quality of melon in hydroponics. Sci. Hortic. 2013, 164, 221-231. [CrossRef]

20. Terry, N.; Ulrich, A. Effects of potassium deficiency on the photosynthesis and respiration of leaves of sugar beet. Plant Physiol. 1973, 51, 783-786. [CrossRef] [PubMed]

21. Ogawa, A.; Taguchi, S.; Kawashima, C. A cultivation method of spinach with a low potassium content for patients on dialysis. Jpn. J. Crop Sci. 2007, 76, 232-237, (In Japanese with English abstract). [CrossRef]

22. Ogawa, A.; Eguchi, T.; Toyofuku, K. Cultivation method for leafy vegetables and tomatoes with low potassium content for dialysis patients. Environ. Control Biol. 2012, 50, 407-414. [CrossRef]

23. Xu, H.; Johkan, M.; Tsukagoshi, S.; Maruo, T. Effect of nutrient quantitative management on potassium and sodium concentration in low-potassium lettuce. Hortic. J. 2021, in press. [CrossRef]

24. Tsukagoshi, S.; Hamano, E.; Hohjo, M.; Ikegami, F. Hydroponic production of low-potassium tomato fruit for dialysis patients. Int. J. Veg. Sci. 2016, 22, 451-460. [CrossRef]

25. Miura, S. Cherry-type tomato cultivation using substrate. In Handbook of Practical Hydroponics; Seibundo Shinkosha Publishing Co., Ltd.: Tokyo, Japan, 2018; pp. 20-21. (In Japanese)

26. Food Composition Database. Available online: https:// fooddb.mext.go.jp/details/details.pl?ITEM_NO=6_06183_7 (accessed on 25 September 2020). (In Japanese)

27. Bradley, D.B. Influence of $\mathrm{K}, \mathrm{Ca}$, and $\mathrm{Mg}$ application on acid content, composition, and yield of tomato fruit. J. Agric. Food Chem. 1962, 10, 450-452. [CrossRef]

28. Sakiyama, R. Influence of potassium and calcium on acid content of tomato fruits in sand culture. J. Jpn. Soc. Hortic. Sci. 1966, 35, 260-368, (In Japanese with English abstract). [CrossRef] 